\title{
The Translatability of Figures of Speech in Khalid Mashaal's Political Speeches: A Critical Discourse Analysis
}

\author{
Ahmad Mohammad Al-Harahsheh ${ }^{1}$ \\ ${ }^{1}$ Translation Department, Yarmouk University, Irbid, Jordan \\ Correspondence: Assistant Professor Dr. Ahmad Mohammad Al-Harahsheh, Translation Department, Yarmouk \\ University, Irbid, Jordan. Tel: 962-772-149-825. E-mail: harahsheh77@yu.edu.jo
}

Received: March 3, 2013 Accepted: March 31, 2013 Online Published: May 17, 2013

doi:10.5539/ijel.v3n3p100 URL: http://dx.doi.org/10.5539/ijel.v3n3p100

\begin{abstract}
This paper focuses on employing CDA method in studying Arabic political discourse in general, and the translatability of figures of speech of Khalid Mashaal's political speeches in particular. This paper also supports the notion that linguistic theory and CDA are useful in studying the translation of political discourse. Three political speeches of Mashaal were translated into English; CDA was used as a theoretical framework to analyze these speeches. The study found that these speeches are full of figures of speech, and the translatability of them into English is problematic, because the translated version lost the flavor of emotiveness that SL text had. This paper also suggests some strategies for translators to overcome these obstacles in translation.
\end{abstract}

Keywords: figures of speech, political disocurse, Critical Discourse Analysis, translation theory, conflict and ideology

\section{Introduction}

The analysis of political discourse has a great importance nowadays. Political discourse is "a complex form of social activity" (Chilton and Schaffner, 1997, p. 207). Political discourse is so common in the world in general and in the Middle East in particular, because it is a conflict area, and it is witnessing the Arab Spring movement that reshapes and reforms different political regimes in the Arab world. Therefore, studying political discourse at this critical moment is crucial, because it adds better understanding to the current political situation in the Middle East.

Mass media play a pivotal role in transmitting political events to public i.e., reporting politics news; interviewing politicians and broadcasting political news, conferences or events by radio or television (Schaffner, 2011). Thus, mass media are the backbone for political discourse in general. The producer of political discourse does not only aim to direct it to a small community local, but s/he also aims to broadcast it internationally. This involves the communicating of language across borders. As a result, translation and interpreting play a significant role in political settings or events (Schaffner, 2011).

Palestine has witnessed a turbulent political situation since 1948. Israel occupied the West Bank and still attacking Gaza Strip from time to time. This makes this area unstable. The notion of conflict stems from power and vise versa. "Conflict refers to a situation in which two or more parties seek to undermine each other because they have incompatible goals, competing interests, or fundamentally different values" (Baker, 2006, p. 2).

In addition, translation and interpreting participate in shaping the way of conflict. To reiterate, translation and interpreting are involved in every stages of conflict, i.e., From the announcing of the war, to mobilizing the troops and to the ending of this war, as there will be conferences and meetings. These actions involve linguistic acts and they need to be interpreted and translated. Therefore, translators and interpreters act as mediator in rendering the message from Source Language (Henceforth SL) to Target Language (Henceforth TL) (Baker, 2006).

Baker (2007) relies on narrative theory to study the behaviours of translators and interpreters when translating texts related to conflicts. Narrative theory is advantageous because it shows our positions in connection with social and political reality; it allows us "see social actors, including translators and interpreters as real-life individuals rather than theoretical abstractions" (Ibid, p. 153) and it allows us to explicate behaviours dynamic terms. Baker (2007) finds that culture, norms and ideologies affect the translator's behaviours. 
Semantic phenomena have been the aim of linguistic, rhetorical, psychological and political studies. Among the semantic phenomena are repetition, emotiveness, collocations and figures of speech i.e., simile and metaphor (Shunnaq, 2000). Translators should be aware of these phenomena when translating from Source Language (SL) into Target Language (TL). In addition, they ought to put into consideration that the connotative meaning of a certain word in the SL is different in the TL. For example, the term "Fascist Islam" has a negative emotive meaning when translated into Arabic الاسلام الفانشي, as this term is marked and unacceptable for Muslims and Arabs. The translation of political discourse is problematic, because it is an abstraction of abstraction (Newmark, 1991). That is to say, political speeches are summarized, translated and shortened by news agencies, embassies and reporters (Newmark, 1991). Moreover, political terms are usually "value-laden - terms are either positive or negative, even when referring to objects or activities" (Newmark, 1991, p. 151).

Political discourse plays a pivotal role in shaping people's thoughts and attitudes, as some politicians function their rhetorical skills and experiences to change and control the people's thoughts and attitudes. To be a successful politician, one should be eloquent orator in order to steer and attract the receivers' emotions, attentions and minds. Politics can be viewed as "a struggle for power, between those who seek to assert and maintain their power and those who seek to resist it" (Chilton, 2004, p. 3). Politics relay heavily on language as a means of affecting language. Therefore, there is a strong relation between language and political activity; it is impossible to disparate them (Chilton, 2004).

Overall, political discourse can be defined as the written or spoken language, verbal or non-verbal, used in politics to steer the emotions of audience to affect their opinions and attitudes. It is distinguished from other types of discourse, because it is intentional, functional, directive to a certain group of people, well-organized, and it is rich in figurative language, i.e., metaphors and similes.

This paper aims at studying the critical linguistic aspects of Mashaal's political discourse as well as the translatability of emotive figures of speech (i.e., simile, metaphor, personification, dysphmism and euphemism), and cultural expressions (i.e., religious, fatalistic, and colloquial) in Mashaal's political speeches. Therefore, this study proposes that studying political discourses from translational and critical linguistic perspectives leads to better understanding. Any translation theory should be emanated from linguistics, because linguistics studies language in its own right and as a tool for rendering meanings (Baker, 2011).

I do agree with Baker $(2011$, p. 4) that linguistics provides translators and interpreters "valuable insights into the nature and function of language." In addition, translators deal with spoken or written texts. As a result, modern linguistics embraces new sub-disciplines such as text-linguistics (the study of text as a communicative event), and pragmatics (the study of the connotative meanings of an utterance or a sentence). Most importantly, the analysis of political texts should include the linguistic or textual features, discursive practices, or manifestations of power structures and/or ideologies that apply to the ST and TT and their cultures (Schaffner, 2004). CDA is employed as a theoretical framework for this study, as focuses on both social, political cultural and linguistic practices of both texts. This study is original and significant, because it is the first study, to my best knowledge, that investigates Arabic political speeches from Critical discourse point of view.

\section{The Integration of CDA into Translation Studies}

The recent Translation Studies (TS) considered translation as a process of transferring intercultural communication i.e., spoken or written discourses within its social context. The employment of CDA has prominently influenced TS. According to CDA, language and social reality are logically related. That is to say, social reality affects the communicative act (translation), and CDA aims to support or alter it (Lande, 2010). CDA assumes that language is a product of society; it is an essential power in reforming the social practices positively or negatively (Wodak and Chilton 2005, Fairclough 2010, 2005, 2003, 1995, van Dijk 2001, Wodak and Meyer 2009, Wodak 2008) (Note 1).

Fairclough (1992, p.74) explains that discourse consists of three elements: social practice, discourse practice (i.e., text production, distribution and consumption of a text) and text. The analysis of each element is interrelated with the other elements. In other words, when we interpret a text, we should analyze and understand the social practices and the discourse practices to reach to a full understanding of the analyzed text. Critical Discourse Analysis (CDA) is essential in analyzing political texts. When we conduct CDA, it is important to understand the social, the cultural and the historical factors around the text production (Dijk, 1995). This paves the way for a better understanding of the analyzed text. At one level, CDA studies the relationship between discourse and the social practices. At another level, CDA studies the relationship between text's producer, power and ideology; it includes several approaches for the social analysis of discourse which has different methodologies, and theories (Fairclough \& Wodak 1997, Pêcheux M 1982, Wodak \& Meyer 2001). 
CDA has been integrated into translation studies. As a result, translation is originated in a particular social context; "the translator's interpretation (understanding) of the source text (ST) and the choices made in the production of the target text (TT) are based on the translator's socio-cultural background, linguistic background and experience with other texts and discourses" (Lande, 2010, p. 4). To illustrate, translators may intentionally or unconsciously pose their views, attitudes or ideologies in TT. Therefore CDA has been utilized in studying political discourses "to analyze the underlying power and ideological struggle created by the text producers" (Lande, 2010, p. 4). According to Lande, (2010, p. 4)

In TS, certain aspects of CDA have been applied to analyze the ideological motivations behind translators' text-linguistic choices in the TT and the translator's role in the interpretation process of the intended meaning of the ST and the production of a new TT.

This study employs a mixed approach quantitative analysis of the repetitions and qualitative analysis which draws on CDA to uncover the social, cultural and ideological meanings behind the original and the translated texts. The present study draws on CDA as a theoretical framework. CDA has been defined as "a critical approach, position of studying text and talk emerging from critical linguistic, critical semiotics and from a socio-political conscious and appositional way of investigating language, discourse and communication" (Dijk, 1995, p. 17).

CDA studies issues related to sexism, colonialism, and other forms of social inequality (Dijk, 1995). In addition, CDA works in a multi-disciplinary typical way, because it studies the relationship between discourse and society (including social cognition, politics and culture).Moreover, CDA studies the relations between "the strategies of dominance and resistance in social relationships of class, gender, ethnicity, race, sexual orientation, language, religion, age, nationality or world-region" (Dijk, 1995, p. 17). Furthermore, CDA deals with the ideologies that play a role in the reproduction of or resistance against dominance or inequality.

\section{Background of the Study}

\subsection{Discursive Practices}

The analysis of discursive event as a social practice refers to several levels of social organization i.e., "the context of situation, the institutional context and the wider social context" (Fairclough, 1992, p. 134). Interdiscursivity, related to intertextuality, is a pivotal concept in analyzing text, because it emphasizes a historical view of texts as transforming the past - existing conventions, or prior texts- into the present." (Ibid, p. 134). Therefore, it is important to give a historical background about the Palestinian Question, its start and the parties who are involved in the conflict in order to have a full image of the discursive practices of the analyzed texts. Palestine was occupied by the UK in the last century.

In 1917, the British government issued the Belfour Declaration, undertaking the support for establishing a Jewish state in Palestine (Note 2). In 1947, the General Assembly voted for the partition of mandatory Palestine into two states one for Arabs and the other for Jewish. This declaration was the first spark that flared up the Arab-Israeli conflict. Gaza Strip remained under the Egyptian authority and the West Bank under the Jordanian rule till the war of 1967. After that, Israel occupied the whole Palestine. Palestinian politicians divided into different militias fighting against the Israel occupation for their land.

The most two prominent movements are Fatih حماس Gatih turned to a political movement, which had peace treaty with Israel for establishing an independent and demilitarized state; it includes the West Bank and Gaza and its capital is Jerusalem. However, Hamas refused the peace negotiation and the political solution that considered it as outrageous, because Israel does not have the right in Palestine and Israeli are occupiers and rapists of land. It also deprives Palestinians from being free on their land, since Israel surrounds the Palestinian state. As a result, Hamas movement was established by Sheik Ahmed Yaseen, a handicapped person, in 1987. The Egyptian Brotherhood committee is considered as the Godfather for Hamas.

Israel attacked Gaza from December 2008 till January 2009. Again, Israel started its attack on Gaza on 11 November, 2012, this attack was called عامود السحاب (lit. Pillar of cloud). It was translated into English as the "Operation Pillar of Defense." This term has a religious connotative meaning for Jewish, because it was mentioned in Exodus 13:21 "By day the LORD went ahead of them in a pillar of cloud to guide them on their way and by night in a pillar of fire to give them light, so that they could travel by day or night."This term also has an emotive meaning as it talks about the rage of God against old Egyptians who enslaved Israeli people at that time; it has an empirical message to Gaza and to Egypt whose president Mohammad Morsi refused this war against Gaza and expressed his country's readiness to support Hamas politically and strategically. On the other hand, the Gazans dubbed their resistance against this attack as حجارة السجيل "stones of baked clay" (Holy Quran105, p. 4). This naming is functional and connotative, since it is quoted from the Holy Quran. It is also 
evidence that this war is a religious one. The term حجارة السجيل "stones of baked clay" has a strong emotive meaning in Arabic that God will fight with Gazans against Israeli, and Hamas weapons will be very effective and destructive.

Khalid Mashal, born in 1956 in Silwad-Ramallah, is one of the most popular Palestinian politicians. He is the chairman of the Hamas political bureau. He is the spokesperson of Hamas, an Islamist armed Palestinian organization and political party. Khalid Mashaal has been one of the most prominent and effective character in Hamas, as he is the official spokesperson of Hamas Movement. He has an influential oratorical style, since his speeches broadcast enthusiasm among the Palestinian people.

In 1997, Israeli Mossad attempted to assassinate him in Jordan, while he was entering his office. One of the two agents of Israeli Mossad came up from behind him, and he directed a device that transmitted fast acting-poison to his left ear. Fortunately, Mashal's guard saw that, immediately ran and hit this agent, then the guards followed them, and they arrested them with the help of Jordanian Police. Directly, King Hussien, the late king of Jordan, asked the Israeli government to send the antidote for the poison to release the two agents and Israel did. Mashal was so lucky, as he survived after this fatal attempt. Nowadays, he is considered as the most effective and prominent character in Hamas organization after Ismail Haniyeh, dismissed prime minister.

\subsection{Methods and Procedures}

Three political speeches of Khalid Mashaal, the head of the political bureau of Hamas, were collected. The first speech was delivered on $24^{\text {th }}$ of April 2006. This speech triggers an internal crisis in Palestine, especially with Fatih movement. This speech had some accusations to Fatih members; he described them as "some of our fellow people conspiring against us". The second was delivered in Damascus on $25^{\text {th }}$ of June 2009 and the last one was delivered in Cairo, Egypt, on $19^{\text {th }}$ of November 2012 during the Israeli attack against Gaza. The speech is the main concern for the present study. The scripts of these speeches were downloaded from the Internet. The reasons for selecting these speeches is that they are considered as the most crucial ones and they are full of emotive figures of speech (i.e., simile, metaphor, personification and euphemism),repetitiveness, cultural, religious and ideological expressions.

These speeches were translated into Arabic, and then the frequencies of some emotive words have been counted and then analyzed from CDA perspective. Next, the translatability of figures of speech, cultural, religious and colloquial expressions are studied based on linking Critical Discourse Analysis (Henceforth CDA) to Translation Studies.

\subsection{Theoretical Framework}

The present study employs three-dimensional models of analysing discourse developed by Fairclough (1992, p.73). Fairclough $(1992,1999$, p.97) explains that discourse can be seen as (i) a language text i.e., spoken or written (ii) discourse practices (text production and text consumption), (iii) socio-cultural practices. In order to create a systematic method for investigating the relationship between text and its social context, Fairclough (1999, pp. 97-98) develops the following method of discourse analysis which includes: a) linguistic description of the language text, (b) interpretation of the relationship between the (productive and interpretative) discursive processes and the text, and (c) explanation of the relationship between the discursive processes and the social processes."

In addition, Al-Hejin's (2012, pp. 317-320) employs three methodological models, which are based on Fairclough's (1992), for applying CDA to translated texts i.e., political discourse. In this study, I will combine the first and the second model together to form a new model (see figure 1 below). This model emphasises: first, translation as re-writing by conducting textual analysis of a translation and then analyse the discursive and socio-cultural practices of the translator operating in the TL domain" (Al-Hejin, 2012, p. 317). It assumes that a translator is subjected to ideological agents or discourse that may affect his or her work; "translation is viewed as a text which reflects the interests of a particular culture or group" (Al-Hejin, 2012, p. 317). Second, "translation as intertextual chain by conducting a comparative CDA of the texts, discursive and social practices of both the SL and TL domains" (Al-Hijen, 2012, p. 318). Intertextuality refers to the use of one text depends upon the knowledge of previously encountered texts. This model is important to understand the motivation behind certain linguistic choices back to the SL and culture to have a suitable understanding of their intended function and discursive impact.

Recontextualisation can be defined as "the dynamic transfer-and-transformation of something from one discourse/text-in-context (the context being in reality a matrix or field of contexts) to another" (Linell, 1998, $\mathrm{p}$. 154). To put it in other words, recontextaulisation involves extricating a part of one context and relocating it into 
another. Aspect of discourse which can be recontextualised includes "linguistic expressions, concepts, and propositions ...values and ideologies... ways of seeing things, and acting towards them, ways of thinking and ways of saying things" (Ibid, pp. 154-155). Thus, when parts of text are reformed or relocating by recontextualisation, these parts will be subject to textual change such as "simplification, condensation, elaboration and refocusing." (Ibid, p. 155). Generally, when a translator recontextualise the SL text, or some parts of it, into TL text, s/he may be ideologically affected by the social practices (i.e., political, cultural...etc.) of the society s/he belongs to, and by the discursive practices (i.e., the interpretation of the text). This model investigates the social and discursive practices related to the SL text before starting the process of translation, because it is essential for a translator to be aware of the social, cultural and political practices connected with the translated text. After that, this model studies the social and discursive practices of the TL text i.e., the proper use of words or expressions, the avoiding of implying the translator ideology on the translated text.

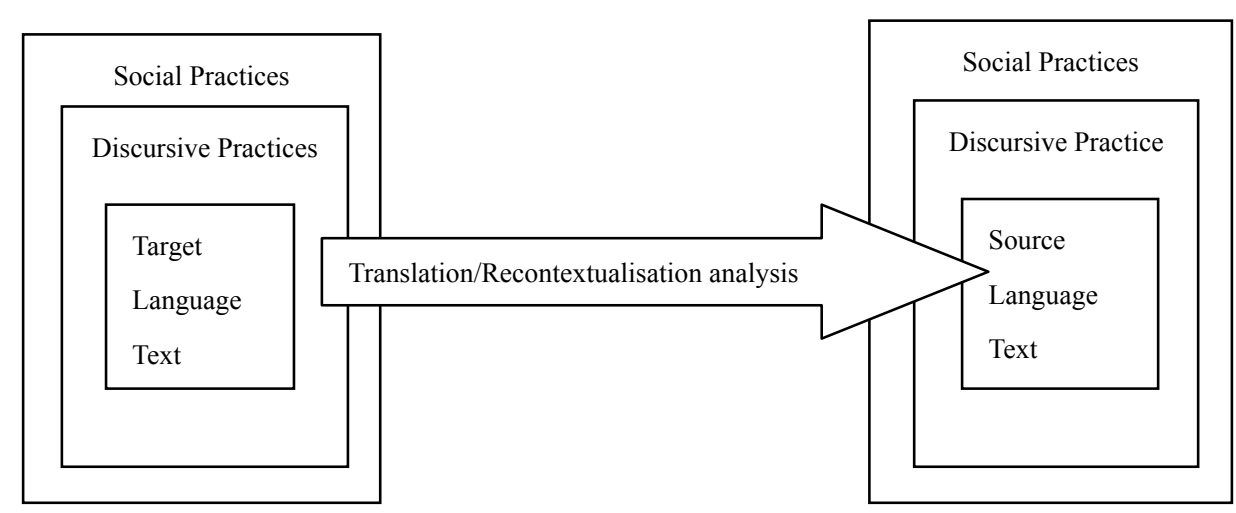

Figure 1. Apply the analysis to both the SL and TL contexts adapted from Fairclough (1992, p. 73)

\section{Findings of the Study}

This section tackles the critical linguistic part of the study. After analyzing Mashaal's speeches, the study observed the repetition of the following emotive words. The order of these words in the table does not reflect its importance.

Table 1. The frequency of repetitive words in Mashaal's political speeches

\begin{tabular}{|c|c|c|}
\hline The word in Arabic & The Translation in English & Frequency \\
\hline حماس & Hamas & 11 \\
\hline فتح & Fatih & 3 \\
\hline منظمة التحرير & Liberation Organization & 2 \\
\hline فلسطين & Palestine & 58 \\
\hline القطاع /غزة & Gaza/ Strip & 22 \\
\hline 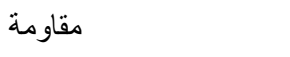 & Resistance & 56 \\
\hline شهداء/شهيد & Martyrs/Martyr & 16 \\
\hline أ أطفال & Children & 8 \\
\hline اسلام/ اسلامية & Islam/Islamic & 21 \\
\hline عربي /عربية & Arab/Arabic & 42 \\
\hline شعبنا & our people & 14 \\
\hline 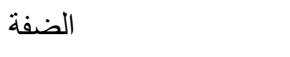 & The West Bank & 17 \\
\hline 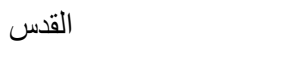 & Jerusalem & 10 \\
\hline 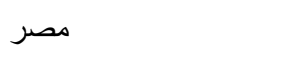 & Egypt & 25 \\
\hline العقل/ الحكمة & Mind/ wisdom & 5 \\
\hline
\end{tabular}




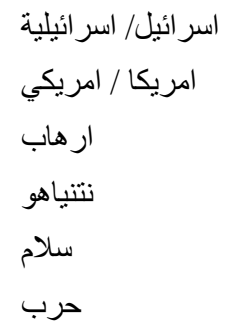

Israel/ Israeli

America/American

Terrorism

Netanyahu

Peace

A discursive glance on table (1), Mashaal repeats "Palestine" and its adjective "Palestinian" 58 times, "Gaza" 22 times, "West Bank" 17 times, and "Jerusalem" 10 times in his three speeches. We can note that the repetition of "Palestine" is functional and communicative. He wishes to send a connotative message to his audience that Hamas' priory aim is to free Palestine and Hamas is an integral part of Palestinian people. It also an indication to Israel and other countries that you cannot isolate Gaza and Gazans from Palestine and Palestinians. Shunnaq (1992, p.32) classifies repetitions in Arabic political discourse into three categories: i) "repetition embedded in the language system and employed by language users"; ii) functional or communicative repetition, and iii) "unnecessary repetition i.e., tautologies or 'pleonasms' which may be part of the utterance, or due to faulty style, figures of speech" (Ibid, p. 32). This study tackles the translation of functional or communicative repetition at the word, utterance and sentence level.

Mashaal also repeats the word "Arabs/Arabic" 42 times while he repeats the word "Islam/Muslims" 21 times. This repetition is functional and Ideological, because he shows the importance of Arabism over Islamism. That is to say, he addresses the Arabs to urge them to do their duties towards Palestine and its people, because they (Arabs) are morally and legally responsible for what is going on in Palestine. Again, the repetition of this Arabism rather than Islam is emotive, since he aims to gain the sympathy of Arabs in general towards his people's suffering. Geographically speaking, Palestine is in the heart of the Arab World.

The repetition of "resistance" for 56 times; "martyr(Shaheed)/martyrs(shuhadaa')"16 times (The word shaheed has stronger emotional meaning than Qateel (Killed), as shaheed is the one who killed for the sake of God and his reward will be the Heaven.); "wisdom/mind" 5 times "war" 21 times and "peace" 2 times is also functional and communicative. It aims at showing the world in general and his audience in particular that Hamas's only choice is resistance against Israel, because of Netanyahu's intransigent policy toward Palestine; peace is impossible under this unjust government that kills innocent people, destroys their houses and occupied their land. This is why he repeats the word "children" 8 times and it has been uses in collocations such as "Netanyahu keeps on shedding civilians' blood and children's blood". Again, he repeats the 'terrorism' only one time in his three speeches آلة التدمير والار هاب الاسر ائيلي "the Israel deconstruction and terrorist machine." Again, he describes the Israeli war against Gaza as terroristic. I will talk about the emotiveness in the second part of the study.

On the other hand, he blames America and European countries, because they do not do their moral and humanitarian duties towards Palestinians, especially Gazans. He repeats "America/American" 19 times; he uses these words within negative emotive collocations such as نرفض الخضوع للشروط الصهيونية الامريكية "we refuse to undergo the Zionist and American conditions." He is trying to connect between Americanism and Zionism, since America is the biggest supporter for Israel in the world. America supports Israel logistically, financially and militarily.

Egypt has been uttered 25 times in his last speech in Cairo on $19^{\text {th }}$, November, 2012. The reason behind this is that Egypt has an opposing stance from the Israeli war against Gaza, and its honorable and great support to Hamas by reacting internationally to make political pressure on Netanyahu to stop war against Gaza. In addition, it reflects his compliment to the Egyptian government and its president who work hard find a settlement for the Palestinian Question. The word "Netanyahu" mentioned 15 times, it occurs within highly emotive collocations such as نتنياهو قاتل الاطفال "Netanyahu is the killer of children" to show the cruelty of him.

\section{Figures of Speech in Mashaal's Political Speeches}

This section deals with the translatability of figures of speech, cultural, religious, fatalistic and colloquial expressions, and the difficulties that translators may encounter and some strategies to overcome these obstacles. Any critical linguistic study of political discourse should take into account the figures of speech i.e., emotiveness, simile, metaphor...etc., because they add flavor to the whole speech and they arouse the emotions, the curiosities 
and the interests of the audience. This may affect the audiences attitudes and thoughts towards the points raised in the speech. I start with one of the most significant figures of speech, emotiveness.

\subsection{Emotiveness}

The emotive meaning arouses from the psychological and ideological states of the producer of the text. The producer of a text can employ neutral/objective vocabulary or emotive/objective ones (Shunnaq, 2012). The producer of the text can express his emotions positively, neutrally or negatively (Shunnaq, 1993). Stevenson's (Note 3) (1963, pp. 21-22) defines emotiveness as "the emotive meaning of a word is a tendency of a word, arising from the history of its usage, to produce (result from) effective responses in people." Hatim (1997, p. 108) also states that:

The expression of emotiveness is closely bound up with semiotic categories such as text type, discourse and genre, as well as with the hierarchical organization of texts or the way they are put together. But, perhaps rather uniquely, emotiveness is the set of relationships obtaining between ideological meaning and the lexico-grammar.

Emotiveness is an aspect of connotation and its translation is problematic to translator, because it depends on his or her proficiency in translating such terms (Al-Azzam, 2005). In other words, the translator's task starts to be difficult one s/he encounters emotive words or stretches of words beyond their referential meaning. Nida (1975) (Note 4) explains that the emotive meaning is distinguished from other kinds of meaning in terms of types and degrees of emotional reaction to the language's expressions. In addition, "the focus of emotive meaning is not language, but speech" (Al-Azzam, 2005, p. 109). Cultural context should be taken into account, when translating or analyzing the emotive meaning of words (Nida, 1964) (Note 5). Newmark (1991, p. 146) also points out that "politics is the most general and universal aspect and sphere of human activity and in its reflection in language it often appears in powerful emotive terms."

Obviously, the emotive meaning of the producer of the text is intentional and functional at the same time, as it aims to convey a certain message particularly in political discourse. In political discourse, the speaker extensively employs the emotive meanings in order to steer the feelings and the sympathy of the audience. The failure and the success of the political discourse weighs by the ability of the deliverer of the speech to reach his or her audiences' emotion to climax. Sometimes the emotive meaning can be unmarked for the deliverer as well as the receivers of the political speech, for instance, Khalid Mashaal calls Palestinians who fight against Israel as "heroes," and the ones who killed are "martyrs" and their reward will be Paradise. Baker (2007, p. 165) explains that the word "martyr" in English is not semantically equivalent to "shaheed." To illustrate, in Arabic the word "shaheed" refers to someone who is killed violently, particularly in war, where they choose to be involved in this war or not." It therefore does not have the overtones of militancy and extremism that the term martyr has come to acquire in English." The emotive meaning of "martyr" is unmarked, i.e., acceptable for Mashaal and Arabs in general. However, it is marked i.e., unacceptable and weird for Israel, the USA and non-Arab countries who consider Hamas and its fighters as terrorists. In addition, Hamas was proclaimed as a terrorist organization by the USA and some European countries.

Mashaal's utilization of emotiveness reveals his people's suffering under the Israeli occupation to their land. Furthermore, he is trying to gain the sympathy of the "world's liberated people" احرار العالم in order to make political pressure on Israel to stop its attack against Gaza. Following Shamma (1978, pp. 90-156) (Note 6) and Shunnaq's (2000) categorization of emotive meaning types. This study adopts this classification which is based on the translational levels of linguistic hierarchy i.e., phonological, syntactic, lexical and semantic levels.

\subsubsection{Emotiveness at the Phonological Level}

Phonological level deals with prosodic features such as sound symbolism, rhythm...etc. (Shunnaq, 2000) Rhythm plays a significant role in displaying emotiveness in political discourse in Arabic, because it makes it so attractive to the text receivers (Ibid). It also imparts a special character to words, so it makes them resonant and audible. Consider the following ample example quoted from Mashaal's speech:

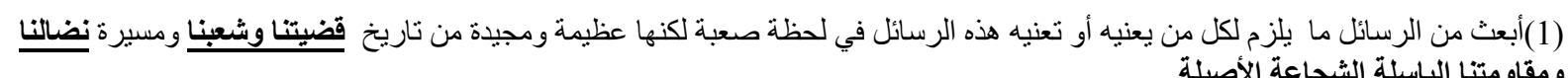

(12) I send what is required of messages to whom they may concern in this hard, but great and glorifying moment in the history of our Question, our people, our struggling march, our courageous and genuine resistance.

In the Arabic version, the use of sound of the morphemes (rhythm) "na" in قضيتنا وشعبنا ونضالنا ومقاومتنا does not appear in English. Therefore, English translation of (1) is less emotive than the Arabic version. The use of such rhythm is functional and expressive, as the speaker tries to get the listeners involved in his or her speech. Again, 
the rhythm "ah" which is the last morpheme in the following words الثجاعة الثجة الباسلِة الاصيلِ (The two words have the same meaning (i.e., repetition of synonyms that end with the same rhythm).

$$
\text { (2) يا أهل غزة يا أهل الضفة يا أهل الـ /48/ يا أهل الثتات هذا توجيه اله }
$$

(2)This is God's guidance, Oh! Gazans, Oh! West Bankers, Oh! the people of 48(those who are under the Israeli rule), Oh! the Palestinians disperse .

In this example, Mashaal prefers to use alliteration to arouse the feelings of his audience. The use of alliteration is common by the Arab politicians; it is rare to have an Arabic political speech without alliteration nowadays. Back to example (2), the use of vocative particle $" o h "$ followed by mentioning all the segments of the هذا توجيه اله "this is God's Guidance" is emotive, because he is calling Palestinian people wherever they are to be patient, and to accept their destiny, since it is God's desire. The English translation cannot render the same sounds of the Arabic ones, and some "the emotive overtones in the Arabic version cannot be transferred to English which leads to what may be termed as 'incongruency' in translation" (Shunnaq, 2000, p. 219).

Overall, the use of the same sound at the end of successive words or alliterations in Mashaal's speeches is common and intentional, because he aims at arousing the emotions of his audience. However, the English translation of these words affect their beauty and effect. It is also problematic for both the translator and the receiver at the same time. For the translator, s/he must be fluent in both Arabic and English, as s/he must look for the equivalent terms and style in the TL. For the receiver, the cultural differences are also problematic, i.e.,

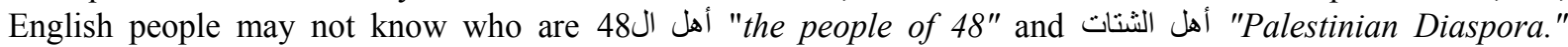
Therefore, the translator should be careful when translating such terms in political discourse, since this will make a gap of understanding of the translated text.

\subsubsection{Emotiveness at the Lexical Level}

In all languages, some words have positive or negative semantic value (Shunnaq, 2000); these words are emotive i.e., "war crimes" جرائم الحرب and "massacres" مجازر. These words are not emotional only in Arabic and English, but also in all languages of the world. Obviously, the emotional tone in Arabic is higher than English (Shamaa, 1978, p. 106) (Note 7). The Arab politicians tend to use higher tone of emotiveness in order to attract the attention of the audiences. Mashaal heavily employs strong emotive lexical and expressions in his speeches to get the sympathy of Arabs and people all over the world with his people's tragedy. The translation of these expressions into English may be problematic, since it is hard to transfer the emotive strength of these expressions into English. Consider the following examples:

$$
\text { (5) و هذه من قداسة فلسطين و بركتها, من يعتدي عليها يقبر فيها ولا ينتصر على شعبها. }
$$

(5) This is due to the holiness and blessing of Palestine, whoever invades it, will be buried in it, and he will never triumph upon its people.

The English translation does not have the same effect as the Arabic original text. For example, the expression is highly emotive in Arabic, because it denotes threatening and confrontation to the enemy or the opponents even if the speaker does not have an equal power like his or her enemy. It also connotes an intimidation to the enemy. Overall, the translation may be incongruent because the overtones of emotiveness in Arabic are toned downed in English translation.

\subsubsection{Emotiveness at the Semantic Level}

This is the most effective and important level, because it includes the figures of speech i.e., metaphor, simile, personification, euphemism and dysphemism. Every study on political discourse should not ignore these figures that add flavor to the political speech. Every language has its own figures of speech (Shunnaq, 1993), because every language has a different linguistic and the cultural prosperities (Al-Hamad \& Al-Shunnaq, 2011). Figure of speech involves the employment of words out of their usual use or their literal meaning in order to add beauty and emotion to the text. These words can be used figuratively or non-literal sense (Al-Hamad \& Al-Shunnaq, 2011).

The use of figures of speech reflects the speaker's ability to produce an emotive and effective speech that will affect the audiences positively. Arabic language is full of figurative or metaphoric expressions, so Arab politicians relay heavily on the use of figurative expressions to deliver a successful speech (Al-Hamad \& Al-Shunnaq, 2011). This study focuses on four figures of speech namely; simile, metaphor, personification, euphemism and dysphemism. 


\subsubsection{Simile}

A figure of speech involves an implicit comparison made between unlike things. Like مثل as (كا) or than are usually used to make a simile. Lucas (1992, p. 223) defines simile as "an explicit comparison between things that are essentially different yet have something in common. It always contains the words 'like' and 'as'". Similes are usually utilised in proverbs (Zuck, 1996). "A simile or metaphor has three parts: the image[topic], the image itself [ the representative figure] and the point of similarity and comparison (the actual meaning of metaphor or simile in the passage)" (Zuck, 1996, p. 106). For example, Lucy (topic/image) looks like (the image) the moon (point of similarity). Mashaal uses similes widely in his speeches; the following are some example quoted from his speeches.

$$
\text { (6) الجرح المصري كالجرح الفلسطيني و العربي و المسلم. }
$$

(6)The Egyptian wound (topic) is like (point of similarity) the Palestine, the Arab and the Muslim wound (image).

$$
\begin{aligned}
& \text { (7) من حق الحكومة أن تنكل مجمو عات لحماية الوطن، وخاصة أنها مجمو عات مخلصة جاءت بلا رو اتب وبلا مخصصات وليست كالمجموعات } \\
& \text { والتثكيلات الأجيرة التي تثترى وتباع بالمال. }
\end{aligned}
$$

The government has the right to form groups to protect the nation, especially those who are working without salaries and allocations, and they (topic) do not like (point of similarity) the traitorous groups and formations that are purchased and sold by money(image).

In example (6), Mashaal uses simile to show his sorrow for the Egyptian children who were killed by a train accident at the time he delivered his speech in Cairo. In addition, it evokes the emotiveness of the audience. That is to say, he would like to gain the sympathy of Egyptians by showing condolence to them on one hand and by drawing their attention to the Israel war against Gaza and the innocent people, especially children who are killed by the Israeli fire. The translatability of such similes may be problematic to translators who do not have cultural background about the producer and the circumstances of the political speech. In example (7), he implicitly refers to some political figures in Fatih movement who work secretly with Israel to kill prominent politicians and leaders in Hamas. Therefore, he describes those as goods, which is purchased and sold. Again, without understanding the political and the social conditions surrounding the text, the translator will have difficulty or poor translation of similes or figures of speech in general. Moreover, the translated version in English loses the effectiveness of the simile and the emotive meaning in the original text. This is another challenge that translators encounter when they translate similes.

\subsubsection{Metaphor}

Metaphor is a figure of speech in which the use of one object refers to another, or substitutes it. It is different from simile that compares two subjects using "like" and "as". The metaphor is purposefully employed to "liven up other types of texts, to make them more colourful, dramatic and witty notoriously in Journalism" (Newmark, 1988 , p. 84). Therefore, metaphor can be used to shape the world or the life of people accurately (Newmark, 1988).

Newmark (1988, p. 85) divides metaphors into five types: dead metaphor- the sense of transferred image is no longer exist, i.e., I do not catch his name, foot filed, top...etc. An example from Arabic is عقارب الساعة "hands of the clock". cliché metaphors "that have perhaps temporarily outlived their usefulness, that are used as a substitute for clear thought, often emotively but without corresponding to the fact of the matter" (Ibid, p. 107). Examples include backwater, breakthrough and set trends in the following "The County School will in effect become not a backwater, but a breakthrough in educational development which will set trends for the future." This kind of metaphors are known and used daily and they are mostly informal i.e., في نهاية المطاف "at the end of the day". Stock metaphor is "an established metaphor which in an informal context is an efficient and concise method of covering a physical and/or mental situation both referentially and pragmatically" (Ibid, p.108); examples include keep the pot boiling.

Adapted Metaphor is the one in which the stock metaphor is slightly changed; they are usually retained as they are "استعار مقتبسة" i.e., الكرة في ملعبهم الان "the ball is in their court now"; يزرع الثقاق بينهم "to sow division between them". Recent metaphor "is a metaphorically neologism" (Ibid, p. 111). That is, the employment of words or terms that have been created recently i.e., المال السياسي" "political money"; تصفية الخصوم السياسيين" head-hunting". Finally, original metaphor "is one created or quoted by SL [Source Language] writer"(Ibid, p. 112). This type of metaphor is easy to translate because it is newly invented i.e., فرصة العمر "a window of hope"; "in the white lamb الوداعة البيضاء في أيام "days

Overall, the employment of metaphor in political discourse is intentional and functional to draw the attention of 
the audience; to gain their sympathy and emotions towards what is being said. Consider the following metaphors in Mashaal's speeches.

(8) ولنا مطالبنا، تقف هذه الحرب المجنونة.

Our demand is to stop this $\underline{\operatorname{crazy}}$ war.

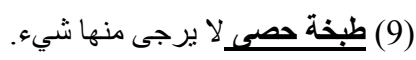

Pebbles cooking which is useless

(10) الصمود العنيد لشعوب المنطقة الحية.

The pertinacious resistance for the people of livable area (Middle East)

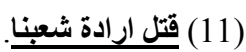

Killing our people's will

(12) في القاهرة المضيئة بلماء شهـائها.

In Cairo that is enlightened by it's martyrs' blood.

(13) بحر دماء الاطفال.

Children's Blood Sea

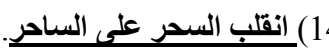

(Lit. His magic is turned against him) or The plan backfired /what goes around comes around

The letters have been delivered to the wrong address

$$
\text { و (17) وقد بدأ نتنياهو يوغل في الدم المدنى ودم الاطفال و النساء. }
$$

Netanyahu started going deeply in the civilian's blood and children and women's blood.

At a glance, Mashaal employs metaphor heavily in his speeches, he either uses recent metaphors, or he creates new metaphors as in (8), (9), (10), (11), (12), (13) and in (17). These metaphors are innovative and highly emotive. By طبخة حصى "Pebbles cooking" in example (9), he refers to the American conspiracy which aims not to solve the Palestinian Question. However, Americans intend not to push the peace negotiation between the Palestinians and the Israelis to leave the area in a chaos, and even these negotiations is like a pebbles cooking which aims to distract the people in the Middle East, and to prevent establishing the Palestinian State. The translation of this metaphor may be problematic, when it is translated into English literally, since it does not convey the equivalent emotive tone like in Arabic. This metaphor is popular in Arabic culture rather than in English one, because it is connected with a real story happened during the rule of Omar Bin Al-khatab, (the Caliph of Muslims during the period of 634-644, who passed by a woman during the night. This woman was boiling pebbles for her hungry children to deceive them that she is preparing food for them so that they may sleep). To be brief, metaphorical images or expressions are used skillfully in Mashaal's speeches to gain the sympathy and to arouse the emotiveness of the audience.

Mashaal is trying to create emotive and impressive metaphor to depict the cruelty of Israeli Prime Minister Netanyahu. He portraits him as a blood sucker in (17). Again, he draws another grotesque picture in (13). This metaphor is emotionally influential, since it depicts the shedding of children's blood by Israeli army in Gaza. It aims to irritate global audiences to interfere to stop this massacre against Gazans.

I do agree with Newmark (1988, p. 88) that translators can use the following strategies for translating metaphors: first, a translator can reproduce the same image in the TL if the image has a comparable or equivalent image in the TL. This strategy is common when translating one-word metaphors. Second, the translator may substitute the image in SL with a standard TL image which does not oppose the TL culture i.e., proverbs. Third, the translator can translate metaphor by simile, keeping the image. Fourth, the translator may converse the metaphor to sense, "the sense must be analyzed componential" (Ibid, p. 91). Sixth, if the metaphor is superfluous, it can be deleted. Finally, "same metaphor combined with sense" (Ibid, p. 91). That is, the translator may add a gloss to an image to make sure that it is understood. To conclude, translators should be careful to transfer the emotive meaning of the metaphor as it is. However, it is a hard task. 


\subsubsection{Euphemism and Dysphemism}

Euphemism is to say something in a pleasant way in order to save the face of the listener. Euphemism "is a word or phrase used as an alternative to a dispreferred expression. It avoids possible loss of face" (Allan, 2001, p. 148). Politicians utilize euphemism expressions to avoid confrontation and political crisis with other politicians or countries. Schaffner (2004, p. 145) refers this strategy as "Legitimisation and delegitimisation: Positive self-presentation and negative presentation of the others, explicitly or implicitly, by using specific translation strategies, by using and abusing texts for purposes of national ideologies." Therefore, translators should be aware of this prominent figure of speech when translating political speeches. Consider the following examples quoted from Mashaal's speech on $24^{\text {th }}$, April 2006.

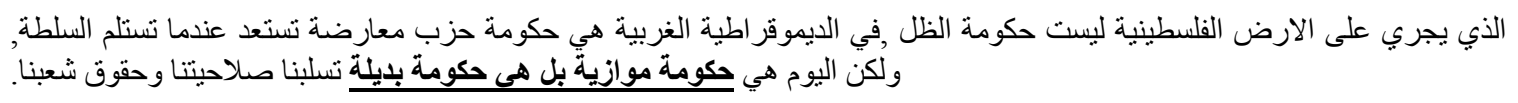

What is going on in the Palestinian land is not a shadow government. In Western democracy, it is a government of opposing party which is being ready when receiving power, but it is an equal government, an alternative government which looting us our powers and our people's right.

In example (18), Mashaal uses the euphemism expression حكومة موازية بل هي حكومة بديلة to mitigate the strength of the expressions and to save the face of people in Fatih movement. Thus, instead of saying كومة بكة عميلة او خائنة "treacherous government", he tends to employ the pleasant term حكومة بديلة او حكومة موازية "alternative government or equal government".

On the other hand, Dysphemism means to say something in unpleasant way. That is, to say something in direct way which may negatively affect the other participant. Burridge and Allan (2001, p. 26) define dysphemism as "an expression with connotations that are offensive either about the denotatum or to the audience, or both, and it is substituted for a neutral or euphemistic expression for just that reason." In Mashaal's speech, I often find him talking directly and critically to his opponents or enemies, i.e., Israel and America. Thus, he employs strong dysphemism expressions in order to arouse the emotiveness of his audience, as Arabs in general believe that America and Israel are the main source of suffering for Palestinians. Consider the following examples:

$$
\text { (19) قاتل الله امريكا, قاتل الله هذا العدوان الظالم الذي نعلم ان قدرة الله اعظم منذ. }
$$

Allah confound America, Allah confound this unjust aggression that we believe Allah's mighty is greater than it.

$$
\text { (20) لن نعترف يإسر ائيل, فثرت اسر ائيل ,و الله لن نعترف بهم. }
$$

We will never recognized Israel as a state, damn on Israel. By Allah, we will never recognize it.

$$
\text { (21) لأنه (نتنياهو) ليس لاديه شرعيه لأنه غاصب وسارق للارض. }
$$

Because he (Netanyahu) has no legitimacy, because he is a land robber and stealer.

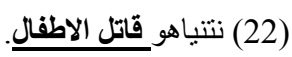

Netanyahu is the children's killer

$$
\begin{aligned}
& \text { (23) امريكا اليوم ايضا تظلم شعبنا وتحاصره, ولكن ما يحزننا ان اوروبا هذه القارة القديمة ذات الحضارة و التاريخ التي تعرف المنطقة سارت }
\end{aligned}
$$

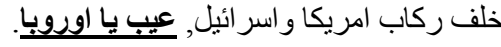

Today, America unjustly deals with our people and blockades them. However, what makes us sad is that Europe, this old continent that has honorable civilization and history, and knows the region, goes behind America and Israel. Shame on Europe.

A quick glimpse at the before-mentioned examples (19-23), we can see how Mashaal employs powerful, colorful and straight dysphemism expressions to amplify the meanings of these expressions, and to arouse the emotions of his audience. His speech style is direct and critical, because he believes that no one is sympathizing with his country and his people. He is trying to raise the tone of his speech by selecting powerful expressions, which may arouse the emotiveness of the people of the world, including Americans and Europeans, who may make a pressure on their governments to change their attitudes towards the Palestinian Question. In addition, dysphemism can be used to humiliate or minimize the enemy. As a way of illustration, Mashaal's weapon is words, so he uses them skillfully to raise the consciousness of his people on one hand and to attack Israel and America on the other hand. In example (19), the use of the expression قاتل اله امريكا "Allah confound America" is a religious expression, he seeks Allah's help in overcoming over America and Israel.

Again, the translation of these expressions may be problematic, because they are direct and may harm the face of the readers in TL. Translators should be honest and careful when translating dysphemism expressions like these, 
and not to change them into euphemistic ones.

\subsubsection{Personification}

Personification is a figure of speech in which the characteristics (i.e., honesty, emotion...etc) of human are attributed to animals or inanimate objects. The function of personification to animate the abstraction of the spoken terms, because these terms are deviations from the usual manner organized in the world (Al-Hamad \& Al-Shunnaq, 2011). These expressions are used in political discourse to give a livable image as well as an expressive and emotive meaning. Translators should be aware of personification and try to keep its emotiveness as possible.

$$
\text { ان سلاح غزة المحدود اربكه ولم تتجح اسلحته. }
$$

Gaza's limited weapon baffles him (Netanyahu) and his weapons failed.

\section{Gaza possesses a lot of fortitude, will and creation}

In example (24), he personifies Gaza's weapon as a human i.e., a man who fears Netanyahu. He gives a livable image to Gaza's weapon that confronts the Israeli army. Again in example (25), he personifies Gaza as a man who possesses fortitude, will and creation. The purpose behind this personification is to highlight the role of Gaza in its struggle against Israel, and it is a warning to Netanyahu not to attack Gaza again.

\section{Cultural Expressions}

Translating the literal meanings of words is an easy task, as the translator can consult a bilingual dictionary to find the appropriate meanings. However, translating culture is problematic, as the translator has to be aware of cultural differences between the SL and TL. For example, Arabic and English have different cultural backgrounds i.e., different languages, societies, religions and norms. To overcome this obstacle, the translator should be aware of these differences in order to have an acceptable or good translation. In political discourse, the matter is more complicated, because the political speech is rich with cultural and religious expressions which the usual translator does not consider. In this section, three cultural aspects are investigated in Mashaal's speeches: religious, fatalistic and social or colloquial expressions.

\subsection{Religious Expressions}

It is axiomatic to say that Mashaal's political speeches are affected by the Holy Quran, since he is a member in Hamas Movement, that belongs to the Brotherhood movement. This movement is an extension to the Egyptian Brotherhood Party, as Egyptian Brotherhood party was the master and the guidance of Hamas when it was established in 1987. The use of Quranic verses as evidence is highly emotive in speech, as Muslims believe that what is said in the Quran is assumptive. In addition, the quotation of these verses in his speech is a strategy for expressing condolences to the families of the dead. It also encourages them to be patient as this war is a test for their patience and belief. Consider the following examples that represent religious intertextuality:

(26) وكان فضل الله عليك عظيما( النساء: 111)

God's goodness towards you is great.(Women: 113)

(27) إن الله اشترى من المؤمنين انفسهم و اموالهم بان لهم الجنة( التوبة: 111)

\section{Indeed, Allah has purchased from the believers their lives and their properties [in exchange] for that they will have Paradise (Attawbeh: 111).}

The employment of Quranic verses in his speech is a witness of consolidation for Gazans. It also reflects religious ideology, as the majority of Gazans are Muslims. Again, this is an encouragement to both the fighters and the Gazans that Allah tests your patience in fighting this cruel enemy to get your freedom; Allah will never leave you alone, because Allah has chosen you for this mission. That is to say, Allah selects the good believers for fighting His and their enemy (according to Mashaal).

\subsection{Fatalistic Expressions}

Fatalistic expressions means that everything happened to a man is a predetermined, man is powerless, and he cannot change his destiny. Arabic language is rich in fatalistic expressions, which are connected with religion. In the Arab society, the one who accept his or destiny is a religious one, because s/he believes what happened to him or her is a test for his or her patience. That is, Allah tests the believers to see whether they succeed this test or not in order to be rewarded in Heaven. Arab politicians play on this chord to arouse the emotiveness of their audience on one hand and to shape their thoughts and their attitudes according to their interests on the other hand. 
In Mashaal's case, the employment of fatalistic expressions is for showing condolences and encouragement for Palestinians to be patient and to accept this destiny. Consider the following ample examples:

$$
\text { (28) (لازم نشعر ان ربنـا معنا }
$$

\section{We have to be sure that Allah is with us}

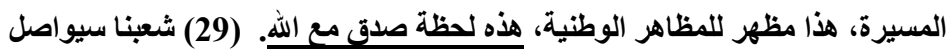

Our people will go ahead (in fighting Israel), this is an aspect of nationalism. This is an honest moment with Allah.

In example (28), he encourages Gazans to stand firmly in front of the Israeli attack against Gaza. He reminds them that Allah is with them, so they should not be hopeless and pessimistic. Nothing will harm them, if Allah's willing goes against it. Again, in example (29), هذه لحظة صدق مع اله is a fatalistic expression, as it is religious in nature and it means that Allah tests our patience and belief, therefore, we have to be honest with Him by accepting His destiny. Translators may have a problem in rendering these expressions in English.

\subsection{Colloquial Expressions}

The usage of colloquial expressions in Arabic political speeches is functional and influential. The purpose of using such expressions is, again, to arouse the feelings of the audiences. Colloquial expressions are more powerful than standard ones. They also express the self-confidence of the deliverer of the speech. Mashaal tend to employ colloquial expressions in his speeches.

(30) اقول ان الذي طلب التهيئة هو نتتياهو, طلبها من شخصيات دولية وطلبها من مصر ودول اخرى, مش حماس ولا المقاومة ولا شعبنا.

I say the one who asks for pacification is Netanyahu. He demands it from international figures, he demands it from Egypt and from other countries, but not Hamas nor the resistance and our people.

In this quotation, the use of the negation particle مش "not" is colloquial, this particle should be ليس in Standard Arabic. The use of colloquial word is more powerful than the standard one, as it gives a strong emotive meaning. Translators should be careful of code-switching in Arabic political discourse.

\section{Conclusion}

Mashaal tends to use powerful emotive expressions to attract the attention of audiences, and to gain the sympathy of his audience in the Arab world or worldwide with the Palestinian Question. The translatability of figures of speech into English is problematic, as it is hard to render the same emotive tone in English language. In addition, there are cultural and ideological difficulties while translating Mashaal's political speeches. Using CDA is useful and helpful in analyzing and translating political discourse in general, because the translation of political discourses without understanding the historical, the social and the cultural context is a hard task. Moreover, linguistic theory is the basis for any successful translated work, because language is a tool for generating meanings, and when translating, translators transfer meaning from one language into another.

\section{References}

Al-Azzam, B. H. S. (2005). Certain Terms Relating to Islamic Observances: Their Meanings with Reference to Three Translations of the Quran and a Translation of Haldith. Boca Raton, Florida: USA.

Al-Hamad, M. Q., \& Al-Shunnaq, M. A. (2011). Emotive Expressions in President Bashar Al-Assad's Political Speeches. Onomazein, 23(1), 149-170.

Al-Hejin, B. (2012). Linking Critical Discourse Analysis with Translation Studies. Journal of Language and Politics, 11(3), 311-335. http://dx.doi.org/10.1075/jlp.11.3.01alh

Allan, K. (2001). Natural Language Semantics. Oxford: Blackwell.

Baker, M. (2006). Translation and Conflict: A narrative Account. London: Routledge.

Baker, M. (2007). Framing Conflict in Translation. Social Semiotics, 17(2). http://dx.doi.org/10.1080/10350330701311454

Baker, M. (2011). In Other Words: A Course Book in Translation. London: Routledge.

Burridge, K., \& Allan, K. (2001). Euphemism \& dysphemism: Language used as shield and weapon. Bridgewater, N.J.: Replica Books.

Chilton, P. (2004). Analyzing Political Discourse: Theory and Practice. London: Routledge.

Chilton, P., \& Schäffner, C. (1997). Discourse and Politics. In Teun van Dijk (Ed.), Discourse Studies: A Multidisciplinary Introduction: Vol. 2. Discourse as Social Interaction (pp. 206-230). London: Sage. 
Dijk, T. A. V. (1995). Aims of Critical Discourse Analysis. Japanese Discourse, 1, 17-27.

Dijk, T. A. V. (2002). Political Discourse and Political cognition. In P. A. Chilton, \& C, Schaffner, Politics and Talk Analytic Approaches to Political Discourse (pp. 203-239). Amsterdam: John Benjamin's Publishing,

Fairclough, N. (1992). Discourse and Social Change. Cambridge: Polity Press.

Fairclough, N. (1995). Critical Discourse Analysis. Harlow: Longman.

Fairclough, N. (1999). Critical Discourse Analysis: The Critical Study of Language. London: Longman

Fairclough, N. (2003). Analysing Discourse: Textual Analysis for Social Research. London: Routledge.

Fairclough, N. (2005). Critical discourse analysis in transdisciplinary research. In R. Wodak, \& P. Chilton (Eds.), op. cit., 53-70.

Fairclough, N. (2010). Critical Discourse Analysis: The Critical Study of Language (2nd ed.). Harlow: Pearson Education.

Fairclough, N., \& Wodak, R. (1997). Critical discourse analysis. In van Dijk (Ed.), Discourse Studies: A multidisciplinary introduction: Vol. 2. Discourse as Social Interaction. London: Sage.

Linell, P. (1998). Approaching Dialogue. Amsterdam: John Benjamins.

Lucas, S. (1992). The Art of Public Speaking. New York: McGraw-Hill Inc.

Newmark, P. (1991). About Translation. Clevedon: Multilingual Matters Limited.

Nida, E. A. (1964). Toward a Science of Translating: With Special Reference to Principles and Procedures Involved in Bible Translating. Leiden: E.J. Brill.

Nida, E. A. (1975). Componential Analysis of Meaning. Belgium: Mouton.

Pêcheux, M. (1982). Language, Semantics and Ideology. London: Macmillan.

Schaffner, C. (2004). Political Discourse Analysis from the Point of View of Translation Studies. Journal of Language and Politics, 3(1), 117-150. http://dx.doi.org/10.1075/jlp.3.1.09sch

Schaffner, C. (2011). Unknown Agents in Political Discourse. Target, 24(1), 103-125. http://dx.doi.org/10.1075/target.24.1.07sch

Shunnaq, A. (1992). Functional Repetition in Arabic Realized Through the Use of Word-Stings with Reference to Arabic-English Translation of Political Discourse. Translation Nouvelles de la FIT, XI(1-2), 37-63.

Shunnaq, A. (1993). Lexical Incongruence in Translation Due to Emotiveness. Turjuman, 2(2), 37-63.

Shunnaq, A. (2000). Arabic-English Translation of Political Discourse. Perspectives: Studies in Translatology, 8(3), 207-228. http://dx.doi.org/10.1080/0907676X.2000.9961389

Shunnaq, A. (2012). Papers and Studies in Arabic Translation. Jordan: Yarmouk University.

Stevenson, C. L. (1963). Facts and Values-Studies in Ethical Analysis. New Haven, CT: Yale University Press.

Van Dijk, T. A. (2001). Critical Discourse Analysis. In D. Schiffrin, D .Tannen, \& H. Hamilton (Eds.), Handbook to Discourse Analysis (pp. 352-371). Malden, MA: Blackwell,

Wodak, R. (2008). The contribution of critical linguistics to the analysis of discriminatory prejudices and stereotypes in the language of politics. In R. Wodak, \& V. Koller (Eds.), Handbook of Communication in the Public Sphere (pp. 291-316). Berlin/New York: de Gruyter.

Wodak, R., \& Chilton, P. (Eds.). (2005). A New Agenda in (Critical) Discourse Analysis: Theory, Methodology, and Interdisciplinarity. Amsterdam/ Philadelphia: John Benjamins.

Wodak, R., \& Meyer, M. (2001). Methods of Critical Discourse Analysis. London: Sage.

Wodak, R., \& Meyer, M. (2009). Critical Discourse Analysis: History, agenda, theory and methodology. In R. Wodak, \& M. Meyer (Eds.), Methods of Critical Discourse Analysis (2nd ed., pp. 1-33). London: Sage.

Zuck, R. (Ed.). (1996). Rightly Divided: Readings in Biblical Hermeneutics. Michigan: Kregel Publications.

Notes

Note 1. Cited in Body, M. I., \& Monacelli, C. (2010). Politics, (Co)text and Genre: Applying CDA to DHA to Interpreter Training. The Interpreters' Newsletter, 15, 51-70. 
Note 2. Shalim, A. (2005). The Belfour Declaration and Its Consequences. In Wm. Roger Louis (Ed.), Yet More Adventures with Britannia: Personalities, Politics and Culture in Britain (pp. 251-270). London: I. B. Tauris.

Note 3. Cited in Shunnaq, A. (2012). Papers and Studies in Arabic Translation. Jordan: Yarmouk University.

Note 4. Cited in Al-Azzam (2005)

Note 5. Cited in Al-Azzam (2005)

Note 6. Cited in Shunnaq, A. (2000). Arabic-English Translation of Political Discourse. Perspectives: Studies in Translatology, 8(3), 207-228.

Note 7. Cited in Shunnaq (2000) 